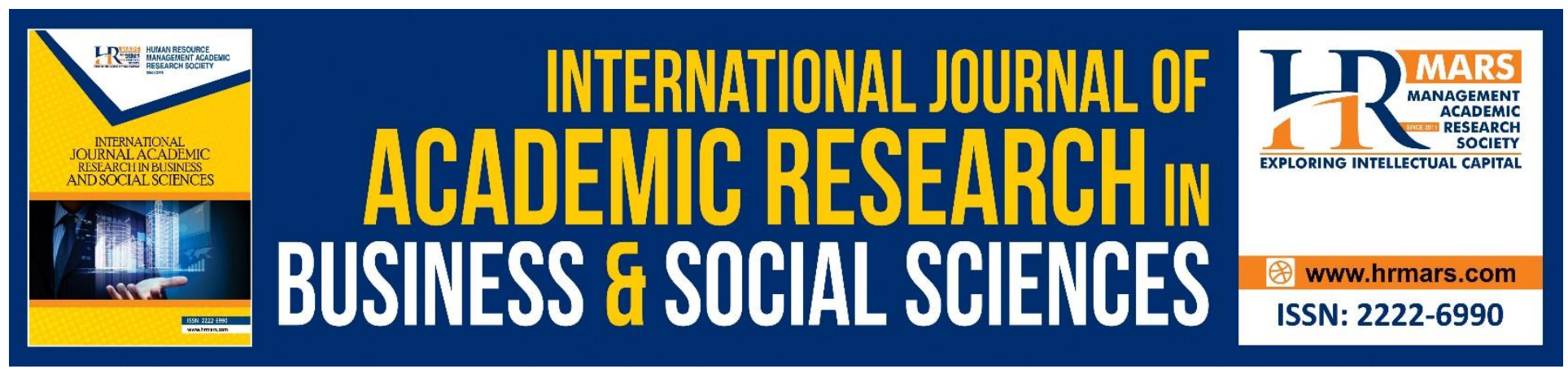

\title{
Analysis of Needs, Criteria and Document for the Development of GIFTED Module for Gifted and Talented Students
}

Amnah Zanariah Abd Razak, Sahlan Surat, Rosadah Abd Majid

To Link this Article: http://dx.doi.org/10.6007/IJARBSS/v10-i7/7593

DOI:10.6007/IJARBSS/v10-i7/7593

Received: 08 April 2020, Revised: 06 May 2020, Accepted: 22 July 2020

Published Online: 29 July 2020

In-Text Citation: (Abd Razak, Surat, \& Abd Majid, 2020)

To Cite this Article: Abd Razak, A. Z., Surat, S., \& Abd Majid, R. (2020). Analysis of Needs, Criteria and Document for The Development of GIFTED Module for Gifted and Talented Students. International Journal of Academic Research in Bossiness and Social Sciences. 10(7), 648-659.

Copyright: (C) 2020 The Author(s)

Published by Human Resource Management Academic Research Society (www.hrmars.com)

This article is published under the Creative Commons Attribution (CC BY 4.0) license. Anyone may reproduce, distribute, translate and create derivative works of this article (for both commercial and non-commercial purposes), subject to full attribution to the original publication and authors. The full terms of this license may be seen at: http://creativecommons.org/licences/by/4.0/legalcode

Vol. 10, No. 7, 2020, Pg. 648 - 659

http://hrmars.com/index.php/pages/detail/IJARBSS

JOURNAL HOMEPAGE

Full Terms \& Conditions of access and use can be found at http://hrmars.com/index.php/pages/detail/publication-ethics 


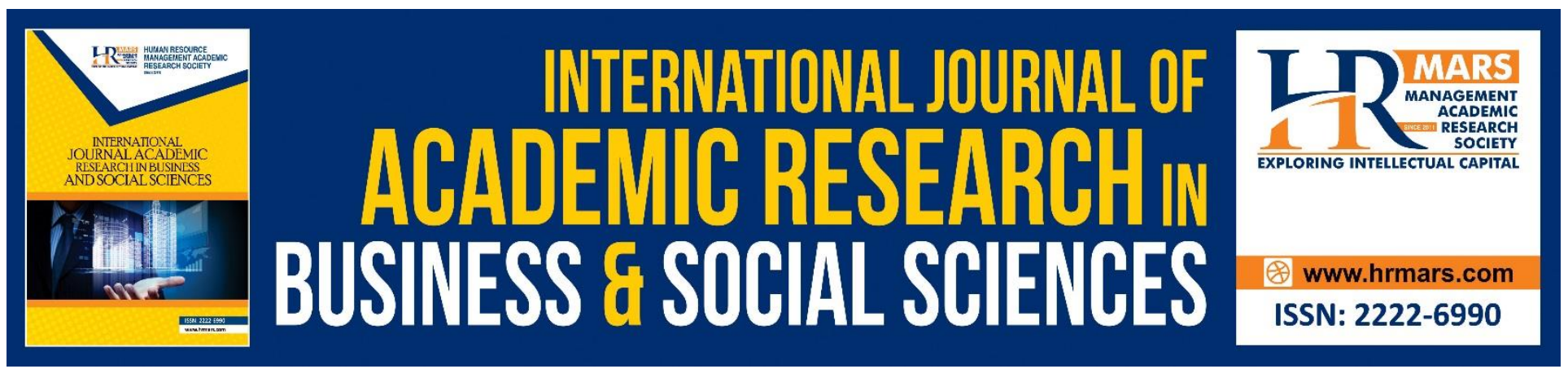

\title{
Analysis of Needs, Criteria and Document for The Development of GIFTED Module for Gifted and Talented Students
}

\author{
Amnah Zanariah Abd Razak, Sahlan Surat, Rosadah Abd Majid \\ Department of Education, Universiti Kebangsaan Malaysia (UKM), Malaysia.
}

\begin{abstract}
This study was conducted to identify the needs for the socioemotional module construction among gifted and talented students. The design of research construction and development was applied based on ADDIE model. Descriptive research design was used to analyze the needs of document analysis, teachers and students' needs analysis, as well as the proposed criteria for the module development. Research sample consists of 11 teachers with experience teaching at the school for gifted and talented students, and 40 gifted and talented students in Negeri Sembilan. The document analysis refers to the counselling cases of referrals throughout 2018 and research review was conducted for the need analysis of teacher, students, and proposed criteria for developing the module. The findings for need analysis research for document analysis showed that the most frequent case to happen involved perfectionism, social anxiety and overexcitabilities. The findings of research review collected from teachers and students who supported the need module development as well as the proposed socioemotional module criteria will help researchers in developing the module. The findings will be able to assist in developing the socioemotional module and simultaneously identifying the appropriate theory to be used as the milestone.
\end{abstract}

Keywords: Gifted and Talented, Needs Analysis, Socioemotional, Perfectionism, Social Anxiety, Overexcitabilities, ADDIE Model.

\section{Introduction}

The Malaysian Education Development Plans (2013-2025) which involves preschool education up to the tertiary level has been executed. Through this policy, the gifted and talented students' education has been managed by a group, namely the students with special education. Therefore, this research was drafted based on the government's requirement in assisting the needs of these special group of students specifically for their socioemotional adjustment.

According to Versteynen, (2013) gifted and talented students go through inner and outer battles to be accepted by their peers, environment, self-interest, motivation and other factors due to their conflict of cognitive maturity.

Imam Ghazali has said; 
INTERNATIONAL JOURNAL OF ACADEMIC RESEARCH IN BUSINESS AND SOCIAL SCIENCES

Vol. 10, No. 7, July, 2020, E-ISSN: 2222-6990 @ 2020 HRMARS

"Everybody has their own intelligences. The intelligence is like a seed in the sand, if the seed is watered and taken care of then it will grow into lush greenery but if it is not, then the seed will wilt."

It is stated in the Quran that the vision of thinking and knowledge, people with knowledge, scholars, intellectuals and the Ulil Albab are acknowledged in the Quran. Allah praises them in surah Makiyah and Madaniyah. Ulil Albab are a group of special individuals and they are mentioned in the Al-Quran 16 times. Ulil Albab uses their intellectual gifts to ponder on the existence and creation of life in this vast expanse of the universe.

"Indeed, in the creation of the heavens and the earth, and alternating between night and day, there are signs for the wise." (Surah Ali Imran: 190)

Hence, we must be more aware of the strengths and weaknesses of students, especially gifted and talented students because cognitive and socioemotional issues cannot be separated. They move in tandem with one another and will lead to conflicts within these students.

The gifted and talented students are distinctive. They are very different from normal children and they are unique Colangelo \& Wood (2015) These children must struggle to adapt themselves to the surrounding (Versteynen, 2013). Early research about them focused on their cognitive intelligence. However, the latest trend of the recent researches is starting to be directed to the needs of socioemotional development of this (Beckmann \& Minnaert, 2018; Kastawi, 2013). Socioemotion, according to Yusof et al., (2017) refers to the capability of an individual to fit in with others in social processes and emotional control.

The research on this matter is crucial to be conducted to discover the area of needs in constructing the gifted and talented students' socioemotional module named GIFTED. GIFTED as being defined by Merriam Webster, as having a great ability, talented. This module uses the ADDIE model approach in its construction of the module progress. ADDIE model consists of five phases in which analyze, design, development, implement and evaluate are involved (Gagné, 2015). Need analysis research is an important first step in structuring its design and development research (DDR) for this socioemotional module. 


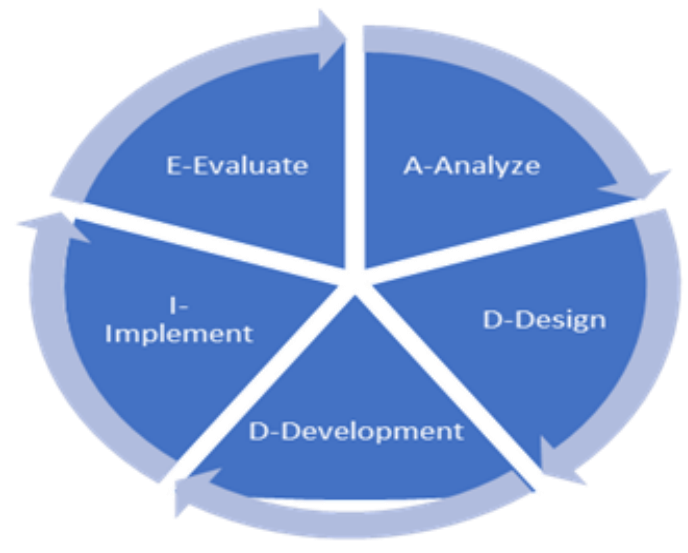

Figure 1: ADDIE Model (Gagne et al 2005)

In developing ADDIE model, the need analysis phase is the first and the key phase in the module development process. In this first needs analysis, all data which are going to be studied, will be identified according to its level of necessity in order to support the next research (Klien, 2007). According to Habibah et al., (2014); Noh, Siraj, Jamil, Husin, \& Sapar, (2015); Rorlinda et al., (2015) needs analysis should be carried out prior to the development of the module; intended to identify the construct which is going to be measured in any modules. The findings of this research are based on the real context of the research environment and assessing the need to resolve the issues and subsequently proceeding to the next level of the module development process.

\section{Research Objectives}

The objectives of this research include:

a) To identify socioemotional issues on research analysis documents of referrals throughout 2018.

b) To identify the need of socioemotional module among teachers and students.

c) To identify suggestions on socioemotional criteria among teachers and students

\section{Methodology}

The methodology used in this research covers a few topics of discussion such as research design, samples, research instruments and data analysis techniques. Each topic of discussion will be elaborated in the next phase of this research.

\section{Research Design}

This research is a survey and document analysis to identify the needs and criteria of socioemotional development module among the gifted and talented students.

\section{Sample}

The respondents of this study were chosen based on purposive sampling. A purposive sample is a non-probability sample that is selected based on characteristics of a population and the objective of the study. 11 teachers and 40 students of lower secondary gifted students at GENIUS Insan College in Negeri Sembilan, Malaysia were sample for this study. 
INTERNATIONAL JOURNAL OF ACADEMIC RESEARCH IN BUSINESS AND SOCIAL SCIENCES

Vol. 10, No. 7, July, 2020, E-ISSN: 2222-6990 @ 2020 HRMARS

\section{Instruments}

The instrument used was adapted from research instrument developed by Jamariah (2017) which had been categorized into two parts;

a) The need instruments.

b) The criteria instrument module.

\section{Document Analysis}

This document analysis was done based on the referrals (related to socioemotional issues) throughout 2018 among the gifted and talented students in gifted college in Negeri Sembilan.

\section{Data Analysis}

In this phase, the data analysis used SPSS (Version 25) to analyze the statistics descriptively. This descriptive statistics findings in use are min, average, and standard deviation. The purpose of this descriptive statistics is to illustrate and explicate the findings of this research.

\section{Research Findings and Discussions}

The research findings are divided into two sections. The first part involves document analysis findings of referrals. The second part of the findings consists of the need and criteria module. The outcomes of the findings will be discussed further in the next writing.

\section{Document Analysis Findings on Referrals}

The document analysis was performed to identify the socioemotional issue that occurred among student's population. It was also performed based on the counselling cases on referrals throughout 2018.

Based on Table 1, there are ten types of socioemotional issues on referrals in 2018 . The highest recorded issue involved social anxiety (19.04\%) followed by overexcitability (12.69\%) and perfectionism (15.87\%). The total number of socioemotional cases on referrals in 2018 was 63 cases. This finding confirms the presence of socioemotional issues among students that requires action. The research limitation in module development lingers around three primary variables: perfectionism, social anxiety, and overexcitability.

Table 1: Counselling cases document analysis referrals in 2018

\begin{tabular}{|l|l|l|l|}
\hline & $\begin{array}{l}\text { Socioemotional } \\
\text { issue }\end{array}$ & $\begin{array}{l}\text { Referred } \\
\text { Cases: }\end{array}$ & Percentage: \\
\hline 1 & Emotional pressure & 6 & 9.523 \\
\hline 2 & Demotivation & 6 & 9.523 \\
\hline 3 & Low self esteem & 5 & 7.936 \\
\hline 4 & Social anxiety & 12 & 19.04 \\
\hline 5 & Perfectionism & 10 & 15.873 \\
\hline 6 & Procrastination & 4 & 6.34 \\
\hline 7 & Underachiever & 5 & 7.936 \\
\hline 8 & Academic problem & 6 & 9.523 \\
\hline 9 & Family problem & 6 & 9.523 \\
\hline 10 & Overexcitability & 8 & 12.698 \\
\hline & Total: & 63 & 100 \\
\hline
\end{tabular}


INTERNATIONAL JOURNAL OF ACADEMIC RESEARCH IN BUSINESS AND SOCIAL SCIENCES

Vol. 10, No. 7, July, 2020, E-ISSN: 2222-6990 @ 2020 HRMARS

These findings reinforce the researches carried out previously on a topic related to perfectionism (Abdollahi \& Abu Talib, 2015; Amnah Zanariah Abd. Razak, Amirah Zainun, 2016; E. Mofield, Parker Peters, \& Chakraborti-Ghosh, 2016; Perrone-McGovern, Simon-Dack, Beduna, Williams, \& Esche, 2015; Zainon Basirion, 2014), social anxiety (Goetz, Preckel, Zeidner, \& Schleyer, 2008; Nunes, Ayala-Nunes, Pechorro, \& La Greca, 2018; Schulze, Renneberg, \& Lobmaier, 2013; Sukur, 2017; White, Graham, \& Blaas, 2018), overexcitability (Aliza Alias, 2014; Karpinski, Kinase Kolb, Tetreault, \& Borowski, 2018; E. L. Mofield \& Peters, 2015; Winkler \& Voight, 2016). The socioemotional issues need to be resolved (Kitsantas, Bland, \& Chirinos, 2017; Mazzoli Smith \& Campbell, 2016; Olszewski-Kubilius, Lee, \& Thomson, 2014) for the students to reach their full potential.

The overall findings of the document analysis referral throughout 2018, need analysis and module development criteria analysis have in some ways assisted researchers in determining the most appropriate prototype before proceeding with the intervention for the most prominent issues regarding perfectionism, social anxiety and overexcitability among the gifted and talented students. According to Mohd Nasri Abdullah, (2017), the findings on analysis document can help to provide information needed by researchers based on real issues. Hence, this needs analysis explains the three main issues that occur in real situations and these three issues are the main variables in the development of the GIFTED module. The three variables are perfectionism, social anxiety and overexcitability amongst gifted and talented students.

\section{Findings on Module Needs Research Review Among Teachers and Students}

The need research involved 40 gifted students in total. The findings as shown in Table 2 show that the highest average for the level of module needs is teachers needing well-organized alternative materials ( $m=4.43$ ), followed by the needs to understand the socioemotional issues of the gifted and talented students $(\mathrm{m}=4.40)$, teachers lacking experience dealing with socioemotional issues $(m=4.30)$, teachers lacking training $(m=4.25)$, and the lowest is no instructional modules based on theories for the gifted and talented students $(m=3.85)$.

These indicate that students see the need for a module that serves as a well-organized teaching-learning material. It also serves as assistance in understanding socioemotional issues caused by teachers who are inexperienced in teaching gifted and talented students. In conclusion, there is a need for a module that is crucial in assisting teachers and simultaneously a module that helps the students' socioemotional adjustment.

Next, the findings on the module needs review among teachers indicate that the highest average for the level of module needs is teachers needing well-organized alternative materials $(m=4.64)$ and teachers lacking experience dealing with socioemotional issues $(m=4.64)$, teachers lacking training $(m=4.45)$, followed by the necessity to understand socioemotional issues $(m=4.09)$ and the lowest is no instructional modules based on theories for the gifted and talented students $(m=3.55)$. These findings indicate that teachers certainly need a well-organized module that can help assist them in the teaching process. Teachers also lack experience that guides them to understand and find ways in developing students' socioemotional state, which is crucial in allowing students to adjust to the socioemotional issues they experience. Apart from that, there is a lack of modules 
INTERNATIONAL JOURNAL OF ACADEMIC RESEARCH IN BUSINESS AND SOCIAL SCIENCES Vol. 10, No. 7, July, 2020, E-ISSN: 2222-6990 @ 2020 HRMARS

developed based on theories concerning these gifted and talented students. Consequently, this module is needed in helping teachers with their teaching process while guiding them in dealing with socioemotional issues among students.

Table 2: Review on Need of Module Among Students and Teachers

\begin{tabular}{|l|l|l|}
\hline Socioemotional issues level of need & $\begin{array}{l}\text { Students } \\
\text { (average/ } \\
\text { standard } \\
\text { deviation) }\end{array}$ & $\begin{array}{l}\text { Teacher } \\
\text { (average/ } \\
\text { standard } \\
\text { deviation) }\end{array}$ \\
\hline $\begin{array}{l}\text { 1.Necessary to understand the socioemotional } \\
\text { issues of the gifted and talented students. }\end{array}$ & $\begin{array}{l}4.40 \\
\text { (sd:0.778) }\end{array}$ & $\begin{array}{l}4.09 \\
\text { (sd:1.044) }\end{array}$ \\
\hline $\begin{array}{l}\text { 2.Teachers lacking experience dealing with } \\
\text { socioemotional issues concerned. }\end{array}$ & $\begin{array}{l}4.30 \\
\text { (sd:0.791) }\end{array}$ & $\begin{array}{l}4.64 \\
\text { (sd:0.505) }\end{array}$ \\
\hline 3.Teachers lacking training & $\begin{array}{l}4.25 \\
\text { (sd:0.809) }\end{array}$ & $\begin{array}{l}4.45 \\
\text { (sd:0.688) }\end{array}$ \\
\hline $\begin{array}{l}\text { 4.No instructional modules based on theories for } \\
\text { the gifted and talented students. }\end{array}$ & $\begin{array}{l}3.85 \\
\text { (sd:1.145) }\end{array}$ & $\begin{array}{l}3.55 \\
\text { (sd:1.368) }\end{array}$ \\
\hline $\begin{array}{l}\text { 5.Teachers needing well-organized alternative } \\
\text { materials }\end{array}$ & $\begin{array}{l}4.43 \\
\text { (sd:0.636) }\end{array}$ & $\begin{array}{l}4.64 \\
\text { (sd:0.674) }\end{array}$ \\
\hline
\end{tabular}

Figure 2 shows the review of the needs of module among students and teachers. These findings indicate that teachers and students support the development of socioemotional module among gifted and talented students to fill the gap that exists within the population of these gifted and talented students.

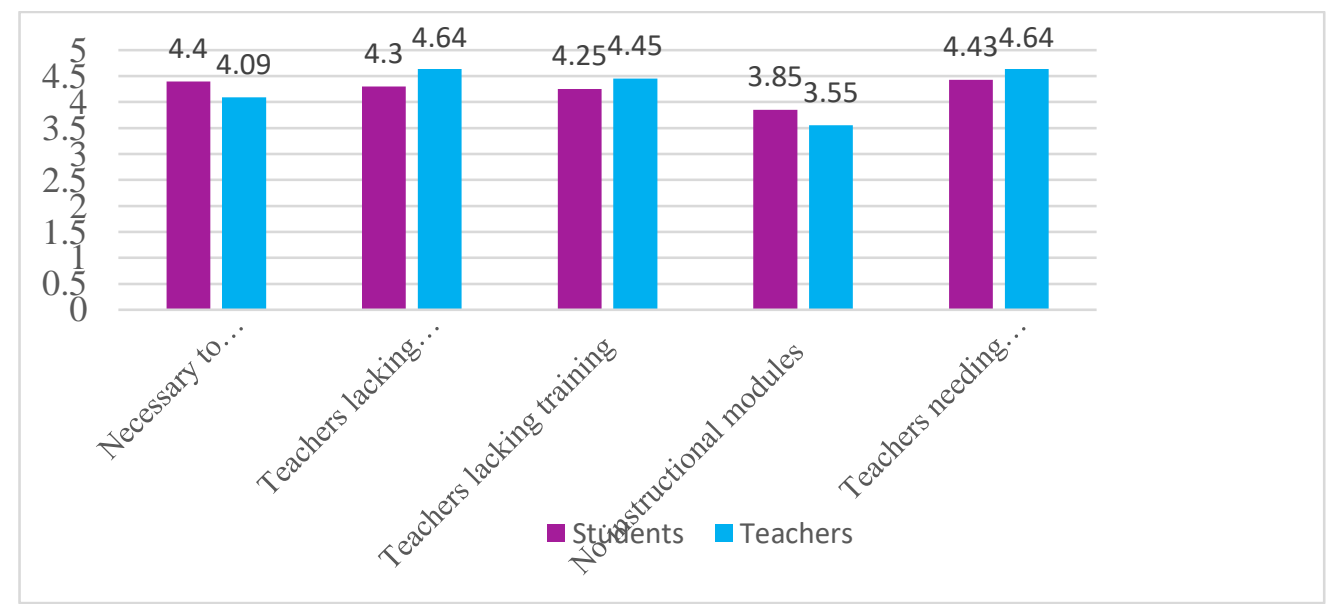

Figure 2: Review on the Needs of Module Among Students and Teachers

The research findings reveal that it is necessary to develop GIFTED socioemotional module for students and teachers. Students need help with their socioemotional issues and teachers need to understand how to help these students handle those issues. Teachers are also in the process of being guided as well as looking for experience. According to Kregel, (2017) and Mazzoli Smith \& Campbell, (2016), teachers must understand the needs and uniqueness of their talented and gifted students 
INTERNATIONAL JOURNAL OF ACADEMIC RESEARCH IN BUSINESS AND SOCIAL SCIENCES Vol. 10, No. 7, July, 2020, E-ISSN: 2222-6990 @ 2020 HRMARS

before teaching them. The fact is the module to be designed must fit the needs of the students (Sidek Mohd Noah \& Jamaludin Ahmad, 2005) in accordance with the gifted and talented theories. Essentially, a module is also needed to provide systematic teaching materials. The data complement the fact that socioemotional module is necessary in assisting the development of these gifted and talented students. Consequentially, the module will help the teachers to execute systematic and organized teachings (Arip, 2018). In summary, teachers and students see the need to develop this module.

\section{Findings on Survey of Criteria and Development Module Among Students and Teachers:}

The review on the module criteria was conducted in alignment with Rusell (1974) who suggested the crucial main criteria in the module development. Among the criteria is that the module must be practical, use plain language, able to evaluate students' level of change, able to help students, and the following module must be organized in a form that is practical to use. Table 3 shows the highest average for the module development criteria among students is module design enables socioemotional adaptations $(m=4.45)$ and module design is manageable $(m=4.45)$, while the lowest is module should be easy to use $(\mathrm{m}=4.37)$. This finding shows that students need the module with the concerned criteria to develop a competent socioemotional among students. Therefore, this needs to be put into consideration when developing the module in the next phase.

Table 3 also shows the review of module development criteria among teachers. The result of the criteria proposed by teachers shows that the highest average for the module development criteria is module must be developed using simple language $(m=4.00)$, module enables evaluation on students' changes $(\mathrm{m}=4.00)$, and module design is manageable $(\mathrm{m}=4.00)$, followed by module should be easy to use $(m=3.91)$ and module design enables socioemotional adaptations $(m=3.91)$. These findings show that the elements that were agreed on must be put into consideration in designing and developing the module.

Table 3: Survey of Criteria and Development Module Among Students and Teachers

\begin{tabular}{|l|l|l|}
\hline Criteria Development Module: & $\begin{array}{l}\text { Students: } \\
\text { (average/standard } \\
\text { deviation) }\end{array}$ & $\begin{array}{l}\text { Teachers: } \\
\text { (average/standard } \\
\text { deviation) }\end{array}$ \\
\hline 1.Module should be easy to use & $\begin{array}{l}4.37 \\
\text { (sd:0 .740) }\end{array}$ & $\begin{array}{l}3.91 \\
\text { (sd:0.944) }\end{array}$ \\
\hline 2.Module use simple language & $\begin{array}{l}4.42 \\
\text { (sd:0.781) }\end{array}$ & $\begin{array}{l}4.00 \\
\text { (sd:0.894) }\end{array}$ \\
\hline 3.Module enables evaluation on students' changes & $\begin{array}{l}4.40 \\
\text { (sd: } 0.841)\end{array}$ & $\begin{array}{l}4.00 \\
\text { (sd:1.095) }\end{array}$ \\
\hline $\begin{array}{l}\text { 4.Module design enables socioemotional } \\
\text { adaptations }\end{array}$ & $\begin{array}{l}4.45 \\
(\mathrm{sd}: 0.639)\end{array}$ & $\begin{array}{l}3.91 \\
\text { (sd:0.701) }\end{array}$ \\
\hline 5.Module design is manageable & $\begin{array}{l}4.45 \\
(\mathrm{sd}: 0.749)\end{array}$ & $\begin{array}{l}4.00 \\
\text { (sd:0.894) }\end{array}$ \\
\hline
\end{tabular}


INTERNATIONAL JOURNAL OF ACADEMIC RESEARCH IN BUSINESS AND SOCIAL SCIENCES Vol. 10, No. 7, July, 2020, E-ISSN: 2222-6990 @ 2020 HRMARS

Figure 3 summarizes the findings on the module development criteria review among students and teachers. The findings on the criteria analysis review support the study by Rusell (1974) that stated five primary requirements in developing this module must be complied with in considering the development of an effective module.

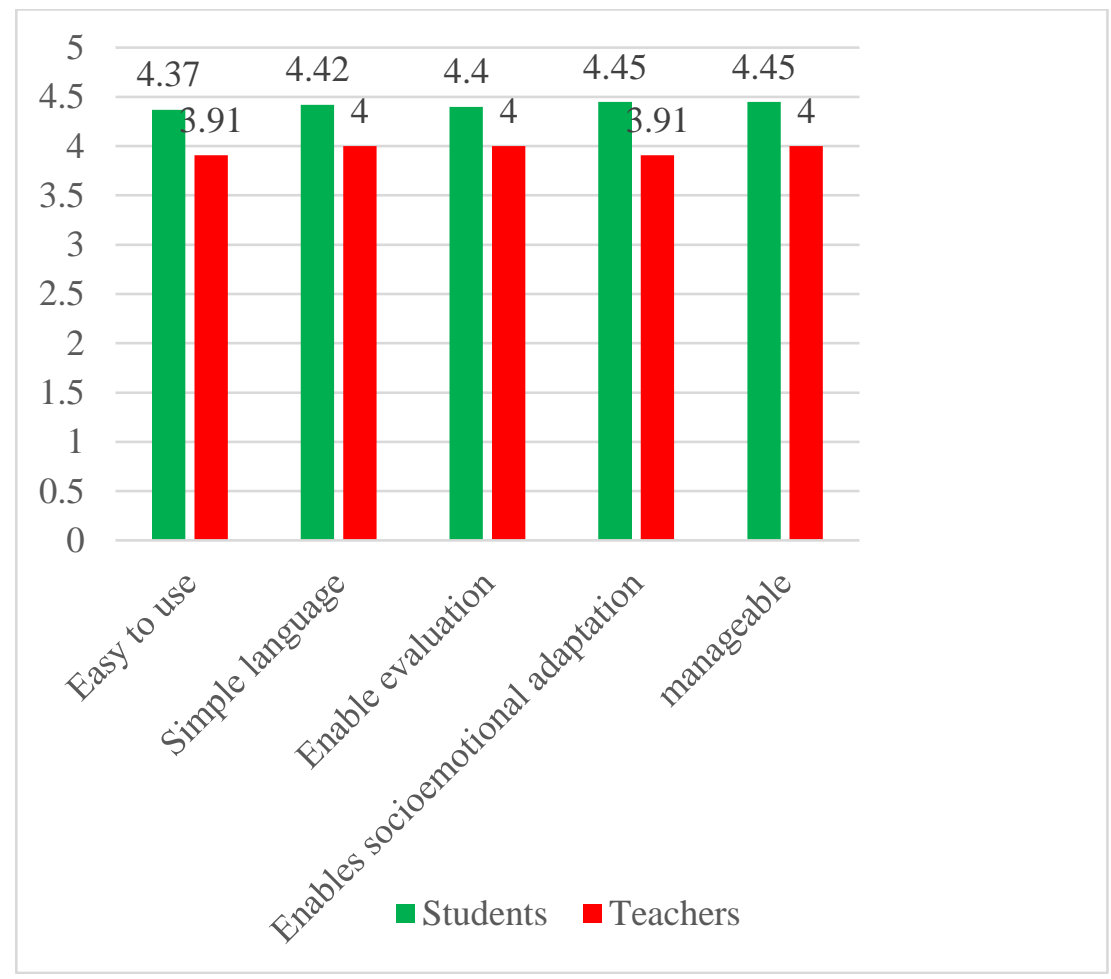

Figure 3: Module Criteria Analysis for Students and Teachers

Next, these review findings on module criteria among teachers and students, showing the highest value for teachers (average 4.0), the module to be designed should use comprehensible language, enables evaluation on students' changes to be carried out. These features suit the module design criteria recommended by Rusell (1974). The findings also show that the developed module must have the usability aspect as discussed by Lund, (2010). The product must be easy for the users in terms of usefulness, satisfaction and ease of use. This module criteria finding will be accounted for during the development of the module.

\section{Summary and Recommendations}

All in all, the document analysis findings expose that perfectionism, social anxiety and overexcitability are the main issues among these gifted and talented students despite other arising issues such as emotional pressure, family problems, demotivation, low self-esteem, fear of being underachievers, and fear of procrastination. In this research, the researcher focused on three issues in which are perfectionism, social anxiety, and overexcitability. Nonetheless, there are numerous other issues to be explored in assisting the gifted and talented students' adaptation process towards their social emotions. 
INTERNATIONAL JOURNAL OF ACADEMIC RESEARCH IN BUSINESS AND SOCIAL SCIENCES Vol. 10, No. 7, July, 2020, E-ISSN: 2222-6990 @ 2020 HRMARS

In determining the concerned development research, ADDIE has become the model approach expected to produce an effective module through five ADDIE processes which are analysis, design, development, execution and evaluation(Robert Maribe Branch, 2009). Moving on from the need analysis finding, the researcher also will choose an appropriate theory to support the data of perfectionism, social anxiety and overexcitability. Based on the sub-construct, each module activity will be planned by taking into consideration the need findings and development criteria module suggested by the teachers and students.

The study of this socioemotional conflicts is in line with the previous researches on the same topic by Akay \& Bratton, (2017); Thavamani ap Selvan \& Grace Annammal Piragasam, (2016); White et al., (2018) Previous studies also recommended that these socioemotional issues are capable of being assisted; through empirical processes by constructing the module. Some studies have constructed modules to resolve these issues among gifted and talented students by Rafidah Kastawi, (2013); Thavamani ap Selvan \& Grace Annammal Piragasam, (2016). Although numerous overseas researches had been carried out, we still lack researches on gifted and talented modules locally, as there are a lot more to be discovered. In addition, these researches have added value on the fact they will not only test the usability of the module but also the evaluation level of the GIFTED module.

In summary, the researches on these socioemotional issues need to be more progressive in order to boost the gifted and talented students' socioemotional adaptation. According to Jones, Greenberg, \& Crowley, (2015), students' issues should be identified since they are in preschool years as the early stage to overcome any arising conflicts when the students grow older. Every part of the society including peers, teachers, support staff and parents should understand their conflicts so the students can reach their maximum potential.

\section{Acknowledgement}

The researcher would like to express her deepest, heartfelt gratitude to the Ministry of Higher Education (MOHE) for the SLAB scholarship awarded and to the Supervisor for endless guidance in assisting the production of this research paper. Unforgotten gratitude especially for GENIUS Insan College, Universiti Sains Islam Malaysia (USIM), Malaysia and University Kebangsaan Malaysia (UKM), Malaysia for their cooperation and support.

\section{Corresponding Author}

Amnah Zanariah Abd Razak

Universiti Kebangsaan Malaysia (UKM), Malaysia.

Email: amzar2010@gmail.com

\section{References}

Abdollahi, A., \& Abu Talib, M. (2015). Emotional intelligence moderates perfectionism and test anxiety among Iranian students. School Psychology International, 36(5), 498-512. https://doi.org/10.1177/0143034315603445

Akay, S., \& Bratton, S. (2017). The Effects of Adlerian Play Therapy on Maladaptive Perfectionism and Anxiety in Children: A single case design. International Journal of Play Therapy, 26(2), 96-110. https://doi.org/10.1037/pla0000043 
INTERNATIONAL JOURNAL OF ACADEMIC RESEARCH IN BUSINESS AND SOCIAL SCIENCES

Vol. 10, No. 7, July, 2020, E-ISSN: 2222-6990 @ 2020 HRMARS

Alias, A. (2014). Profil keterujaan luar biasa pelajar pintar intelek dan kaitannya dengan keupayaan kognitif. Universiti Kebangsaan Malaysia.

Basirion, Z. (2014). Profil keinginsempurnaan pelajar pintar akademik dan hubungannya dengan gaya keibubapaan dan personaliti. Universit Kebangsaan Malaysia (UKM).

Beckmann, E., \& Minnaert, A. (2018). Non-cognitive Characteristics of Gifted Students With Learning Disabilities : An In-depth Systematic Review. 9(April). https://doi.org/10.3389/fpsyg.2018.00504.

Colangelo, N., \& Wood, S. M. (2015). Counseling the gifted: Past, present, and future directions. Journal of Counseling and Development. https://doi.org/10.1002/j.1556-6676.2015.00189.x

Gagné, F. (2015). Academic talent development programs: a best practices model. Asia Pacific Education Review, 16(2), 281-295. https://doi.org/10.1007/s12564-015-9366-9

Goetz, T., Preckel, F., Zeidner, M., \& Schleyer, E. (2008). Big fish in big ponds: A multilevel analysis of test anxiety and achievement in special gifted classes. Anxiety, Stress and Coping, 21(2), 185-198. https://doi.org/10.1080/10615800701628827

Habibah @ Artini, R., Zaharah, H., Ridhuan, M. J., Arifin, A. S., Saedah, S., \& Rabihah, N. M. N. (2014). Aplikasi Teknik Fuzzy Delphi Terhadap Keperluan Aspek 'Riadhah Ruhiyyah' Untuk Profesionalisme Perguruan Pendidikan Islam. The Online Journal of Islamic Education, 2(2), 53-72. Retrieved from http://ejournal.um.edu.my/filebank/published_article/6497/Article_5_V2_12_Jun2014.pdf

Jones, D. E., Greenberg, M., \& Crowley, M. (2015). Early social-emotional functioning and public health: The relationship between kindergarten social competence and future wellness. American Journal of Public Health. https://doi.org/10.2105/AJPH.2015.302630

Karpinski, R. I., Kolb, K. A. M., Tetreault, N. A., \& Borowski, T. B. (2018). High intelligence: A risk factor for psychological and physiological overexcitabilities. Intelligence, 66(November 2016), 8-23. https://doi.org/10.1016/j.intell.2017.09.001

Kitsantas, A., Bland, L., \& Chirinos, D. S. (2017). Gifted Students' Perceptions of Gifted Programs: An Inquiry into Their Academic and Social-Emotional Functioning. Journal for the Education of the Gifted, 40(3), 266-288. https://doi.org/10.1177/0162353217717033

Klien, R. C. R., \& J. D. (2007). Design and development research - Method, strategies and issues. New Jersey: Lawrence Erlbaum Associates Publishers, London.

Kregel, E. A. (2017). Addressing the social, emotional, and academic needs of gifed high school students. (2015).

Lund, A. M. (2010). Usability Interface Measuring Usability with the USE Questionnaire. October.

Smith, M. L., \& Campbell, R. J. (2016a). So-called giftedness and teacher education: Issues of equity and inclusion. Teachers and Teaching: Theory and Practice. https://doi.org/10.1080/13540602.2015.1055448

Smith, M. L., \& Campbell, R. J. (2016b). So-called giftedness and teacher education: Issues of equity and inclusion. Teachers and Teaching: Theory and Practice, 22(2), 255-267. https://doi.org/10.1080/13540602.2015.1055448

Mofield, E. L., \& Peters, M. P. (2015). The Relationship between Perfectionism and Overexcitabilities in Gifted Adolescents. Journal for the Education of the Gifted, 38(4), 405-427. https://doi.org/10.1177/0162353215607324

Mofield, E., Parker Peters, M., \& Chakraborti-Ghosh, S. (2016). Perfectionism, Coping, and Underachievement in Gifted Adolescents: Avoidance vs. Approach Orientations. Education 
INTERNATIONAL JOURNAL OF ACADEMIC RESEARCH IN BUSINESS AND SOCIAL SCIENCES

Vol. 10, No. 7, July, 2020, E-ISSN: 2222-6990 @ 2020 HRMARS

Sciences, 6(3), 21. https://doi.org/10.3390/educsci6030021

Muhamad, J., Razali, M., Raja, Y., Nahar, A., \& Adnan, R. (2017). Needs and Criteria in Developing Creative Movement Module for Preschool Children. International Journal of Academic Research in Business and Social Sciences, 7(2), 2222-6990. https://doi.org/10.6007/IJARBSS

Noh, N. M., Siraj, S., Jamil, M. R. M., Husin, Z., \& Sapar, A. A. (2015). Design of guidelines on the learning psychology in the use of facebook as a medium for teaching \& learning in secondary school. Turkish Online Journal of Educational Technology, 14(1), 39-44.

Nunes, C., Ayala-Nunes, L., Pechorro, P., \& La Greca, A. M. (2018). Short Form of the Social Anxiety Scale for Adolescents among community and institutionalized Portuguese youths. International Journal of Clinical and Health Psychology, 18(3), 273-282. https://doi.org/10.1016/j.ijchp.2018.06.001

Olszewski-Kubilius, P., Lee, S. Y., \& Thomson, D. (2014). Family environment and social development in gifted students. Gifted Child Quarterly, 58(3), 199-216.

https://doi.org/10.1177/0016986214526430

Perrone-McGovern, K. M., Simon-Dack, S. L., Beduna, K. N., Williams, C. C., \& Esche, A. M. (2015). Emotions, Cognitions, and Well-Being: The Role of Perfectionism, Emotional Overexcitability, and Emotion Regulation. Journal for the Education of the Gifted, Vol. 38.

https://doi.org/10.1177/0162353215607326

Kastawi, R. (2013). Pembinaan Modul Terapi Seni (MOTES) dan Penggunaannya Dalam Proses Kaunseling Pelajar Pintar Dan Berbakat. Universiti Kebangsaan Malaysia.

Robert Maribe Branch. (2009). Instructional Design The ADDIE. Athens: Sage Publications,Inc.

Rusell, J. (1974). Modular Instruction: A Guide to the Design, Selection, Utiliziation and Evaluation of Modular Materials. New York: New York :Publishing Company.

Schulze, L., Renneberg, B., \& Lobmaier, J. S. (2013). Gaze perception in social anxiety and social anxiety disorder. Frontiers in Human Neuroscience, 7(December), 1-5. https://doi.org/10.3389/fnhum.2013.00872

Noah, S. M., \& Ahmad, J. (2005). Pembinaan Modul-Bagaimana Membina Modul Latihan dan Modul Akademik. Serdang: Penerbit Universiiti Putra Malaysia Serdang.

Sukur, A. (2017). Relationship Between Emotions and Social Assessment. International Journal of Education, Psychology and Counseling, 2(5), 298-309.

Versteynen, L. (2013). Issues in the social and emotional adjustment of gifted children: What does the literature say? New Zealand Journal of Gifted Education, 13(1), 1-8.

White, S. L. J., Graham, L. J., \& Blaas, S. (2018). Why do we know so little about the factors associated with gifted underachievement? A systematic literature review. Educational Research Review. https://doi.org/10.1016/j.edurev.2018.03.001

Winkler, D., \& Voight, A. (2016). Giftedness and Overexcitability: Investigating the Relationship Using Meta-Analysis. Gifted Child Quarterly, 60(4), 243-257. https://doi.org/10.1177/0016986216657588

Yusof, R., Ishak, N. M., Hamdan, J., Hassan, A., Radzi, A. M., Elmi, T., \& Muda, A. T. (2017). Kajian Isu-Isu Sosio-Emosi Dalam Kalangan Pelajar Pintar Dan Berbakat Di Malaysia. E-JURNAL PENYELIDIKAN DAN INOVASI, 4(1), 13-29.

Yusop, Y. M., Sumari, M., Mohamed, F., Said, S., Azeez, M. I. K., \& Jamil, M. R. M. (2015). The needs analysis in self-concept module development. The Malaysian Online Journal of Educational Science, 3(1), 44-55. 